\title{
ФОРМАЛ ГРАММАТИКА НАЗАРИЯСИ
}

\author{
Жураева Нилуфар Вайитовна, \\ Чирчиқ давлат педагогига инситути, \\ информатика кафедраси доценти \\ Хасанова Суманбар Хамрокуловна, \\ Чирчик давлат педагогига инситути, \\ информатика кафедраси ўқитувчиси
}

Аннотация: Мазкур мақолада сунъий тиллар, уларнинг классификацияси ва ишлаш прициплари хақида маълумот берилган. Шу принцип асосида табиий тил, яъни ўзбек тили мисолида, формал грамматикаси келтирилган. Олинган натижалар ўзбек тили ва адабиёти йўналиши талабалари учун компьютер лингвистикаси дарсларини ўтишда кўлланилиши мумкин.

Калит сўзлар: табиий тил, компилятор, транслятор, интерпритатор, формал грамматика, синтаксис, лексема.

Компьютерлар билан мулоқот қилиш учун одамларнинг табиий мулоқот тилларидан фарқ қиладиган махсус тиллар ишлаб чиқилади, улар сунъий тиллар дейилади. Сунъий тиллар, бир томондан, одамлар учун кулай ва тушунарли бўлиши керак, бошқа томондан, курилмалар томонидан “идрок” этилиши керак. Ушбу талабларни битта тилда бирлаштириш қийин вазифа, шунинг учун инсон тушунадиган матнларни қурилма тушунадиган тилга алмаштириш воситалари кўлланилади. Ушбу воситалар трянстляторлар яъни таржимонлар деб номланади.

Таржимонни талқцин қилиш ёки тузиш мумкин. Биринчисида у кириш тили учун транслятор, иккинчисида эса компилятор деб номланади. Трянслаторлар, интерпритатор ва компилятор турларига ажралади.

Интерпритатор кириш тилининг гапларини кетма - кет ўқийди ва тахлили қилиб дархол бажаради. Компилятор (тузувчи) тилнинг жумлаларини бажармайди, балки кейинчалик натижани олиш учун дастур тузади. Компиляторга инсон тилидаги матн берилади, натижавий матн эса курилма тушинадиган кўринишда тузилади.

Компиляторнинг иши бир неча босқичлардан иборат бўлиб, улар кетмакет бажарилиши мумкин. Компиляторнинг ишининг биринчи босқичи лексик тахлил дейилади, дастури эса - лексик тахрирчи (ЛТ). Лексик тахлилчига 
кириш тилидан белгилар кетма-кетлиги киритилади. ЛТ ушбу кетмакетликда лексик бирликлар деб аталадиган энг содда конструкцияларни ажратиб олади. Лексик бирликларга мисол қилиб, идентификаторлар, рақамлар, операцион белгилар, хизмат сўзлари ва бошқаларни олиш мумкин. ЛТ матндаги лексик бирликларни лексема деб номланган, уларнинг ички кўринишлари билан алмаштиради. Лексема таркибида лексик бирликлар синфи ва уларнинг таърифи хақида маълумот бўлиши мумкин.

Компилятор ишининг иккинчи босқичида синтактик тахрирловчига (CT) лексемалар кетма кетлиги киритилади, бу ўз навбатида, харакатлар белигиси кетма кетлигидан иборат оралиқ кодга алмаштирилади.

Компилятор ишининг учинчи босқичида чиқувчи матн тузиш амалга оширилади. Бу жараённи амалга оширадиган дастур чикувчи матн генератори(Г) деб номланади. Генератор ўнга кирувчи хар бир харакат белгисига, чикувчи тилдаги бир ёки бир неча буйруқларни мослайди. Чикувчи тил сифатида курилма буйруқлари, ассемблер буйруқлари ёки бошқа бир тилнинг операторлари ишлатиши мумкин.

Компиляторни тузиш учун кириш ва чиқиш тилларининг аниқ ва бир қийматли таърифи талаб қилинади. Бундай талаб тилнинг мақбул конструкцияларини куриш қоидаларини аниқлашда керак бўлиши мумкин. Ушбу қоидалар тўплами тил синтаксиси деб аталади. Бундан ташқари, топшириқ ўз ичига хар бир конструкция маъноси ва мақсад тавсифидан иборат бўлиши керак. Ушбу тавсиф тилнинг семантикаси деб номланади.

Киритилган матнни ўрнатилган қоидалар асосида тузилган белгилар кетма-кетлиги деб қараш мумкин. Формал тил ёки грамматика деб, матнларни ифодалашда ишлатилган белгилар кетма-кетлигидан иборат математик моделга айтилади.

Қуйида формал грамматика қоидалари ва талаблари асосида табиий тил Ўзбек тили мисолида формал грамматикасини бериш харакат қилинган.

\section{Формал грамматика Ўзбек тили мисолида}

Тилнинг асосий элементлар бўлган тушунчаларга формал грамматика нуқтаи назарида таъриф бериб ўтамиз:

С̆̈з - маънога эга бўлган, муаян тилнинг луғатида мавжуд белгилар кетма кетлиги. Тилнинг лексикаси деб, тилда жоиз бўлган сўзлар тўпламига айтилади.

Гап - сўзларнинг мураккаб бўлган конструкциялар бирлашмасига айтилади. Тил бу гаплар тўпламидир. Гаплар синтактик қоидалар асосида 
сўзлар ва содда гаплардан тузилади.

Синтаксис деб, тўғри тузилган гапларнинг тавсифи тушунилади.

Алфавит, лексика ва синтаксис тилдаги жоиз конструкциялар тўпламини ва конструкциялар орасидаги ички муносабатларни тўлиқ аниқлайди.

Синтаксис қоидалар тўплами тилнинг грамматикасини ташкил этади. Синтаксис қоидаси тўғри гапларни хосил қилиш процедурасини ёки гапнинг “тўғрилигини” (яъни гапни мазкур тилга тегишлилигини) аниқлаш процедурасини ифолаши мумкин. Биринчи холатда, грамматика генератив, иккинчи - аниқланувчи грамматика дейилади.

Мисол: Айтайлик $\mathrm{G}_{0}$ грамматика кўйидаги қоидалар тўплами билан аниқланган.

$$
\begin{aligned}
& \langle\text { гап } \rightarrow\langle\text { эга }>\langle\text { кесим }\rangle \\
& \langle\text { үга }>\langle\langle\text { от }> \\
& <\text { үга }>\rightarrow\langle\text { <олмош> } \\
& <\text { от }>\rightarrow \text { олма } \\
& <\text { олмош> } \rightarrow \text { у } \\
& <\text { кесим }>\rightarrow<\text { феъл шакли }> \\
& <\text { феълли шакли }>\rightarrow \text { тушди }
\end{aligned}
$$

$\rightarrow$ белги «бу... дегани» деб ўқилади. У хар бир қоидани 2 қисмга ажратади: ўнг ва чап.

Маълум қисқартиришларни киритилса, $\mathrm{G}_{0}$ грамматикани қисқача куйидагича ёзиш мумкин:

$$
\begin{aligned}
& <Г>\rightarrow\langle Э><К> \\
& <Э>\rightarrow<\text { ОТ }> \\
& <Э>\rightarrow<\text { ОЛМ }> \\
& <\text { ОТ }>\rightarrow \text { олма } \\
& <\text { ОЛМ } \rightarrow \text { у } \\
& <\text { К } \rightarrow<\text { ФШ }> \\
& <\text { ФШ } \rightarrow \rightarrow \text { туШди }
\end{aligned}
$$

Ихтиёрий грамматиканинг қоидалар тўпламини $P$ деб белгилаймиз. Қоида таркибидаги белгилар $V$ луғатни ташкил этади.

$$
V \quad=\{\langle\Gamma\rangle,\langle Э\rangle,\langle\mathrm{K}\rangle,\langle\mathrm{OT}\rangle,\langle\text { ОЛМ }\rangle,\langle Ф Ш\rangle, \text { олма, У, тушди }\}
$$

Одатда, луғат элементлари катта харфлар билан белгиланади. $V$ луғатдаги барча чекли белгилар (қаторлар) кетма кетлиги тўплами хамда бўш қаторни $V^{*}$ деб белгилаймиз. $V *$ тўплам элементларини кичик харфлар билан белгиланади. $V$ тўплам иккита тўплам остига бўлинади: 1) $P$ 
қоиданинг фақат ўнг томонига кирувчи $T$ символлар қисм тўплами $(T=\{$ олма, у, тушди $\})$; 2) $N$ қисм тўплам $=V \backslash T(N=\{<\Gamma>,<Э>,\langle\mathrm{K}>,\langle\mathrm{OT}>$, $<$ ОЛМ $>,<\Phi Ш>\})$.

$T$ қисм тўпламнинг символлари терминалли ёки терминал (чекли)деб номланади. N қисм тўплам элементлари эса терминал бўлмаган ёки уззгарувчи дейилади. Грамматикада, терминал бўлмаган символлар ажралиб туради. Уни грамматиканинг бошланғич (аксиома) белгиси дейилади ва у $A$ ёки $S(A$ $=\{<\Gamma>\})$. Бу белги аникланувчи тилни ифодалайди.

$G=\{V, T, P, A\}$ ни аниқлайдиган $G$ грамматикани, $P$ қоидалар тўплам элементлари қуйидаги кўринишга эга : $x \rightarrow y, \quad\left(x \neq y, x \in(V \backslash T)^{*}, y \in V^{*}\right)$, генератив дейилади, $x \rightarrow y$ кўринишдаги қоида генератив қ̧оидалар ёки уррнига куйиш қондаси дейилади.

\section{Формал тиллар}

$G$ генератив грамматика $\mathrm{L}(G)$ тилни хосил қилади. Бу қандай бўлишини кўриш учун кўшимча таърифларни киритамиз.

$x \in V^{*}$ қатор тўғридан-тўғри $y \in V^{*}$ ( $x \Rightarrow y$ деб белгилаймиз) қаторни хосил қилади агар: $x=p U q, y=p z q$. Бу ерда $p \in V^{*}, q \in V^{*}$, ва $U \rightarrow z \in P$ қоида мавжуд. Бошқача қилиб айтганда, $y$-бу х символнинг тўғридан-тўғри хосиласи (келиб чиқиши) бўлади, агар қоида бўйича у ни х га терминал бўлмаган $\mathrm{U}$ белгисини $\mathrm{z}$ қатори билан алмаштириш орқали олиниши мумкин бўлса. Мисол: $\mathrm{G}_{0}$ грамматикасида $У$ тушди қатори , $<\mathrm{OЛМ}>\mathrm{V}$ қоидани қўллаб олинган $\langle$ ОЛМ $>\rightarrow$ тушди қаторининг хосиласи.

$x \in V^{*}$ қатор $y \in V^{*}$ қаторни хосил қилади $\left(x^{*} \Rightarrow y\right.$ каби белгиланади), агар шундай $x=x_{0}, x_{1}, \ldots, x_{n}=y$ қатор мавжуд бўлсаки, $x_{i} \Rightarrow x_{i+1}, \quad i=0,1, \ldots, n-$ 1 ўринли бўлса. Бундай кетма-кетлик қатори келтириб чиқ̧ариш дейилади. Мисол. $G_{0}$ грамматикада $У$ тушди қатори $\langle\Gamma\rangle$ қаторнинг хосиласи:

$$
\langle\Gamma\rangle \Rightarrow\langle\text { Э }\rangle\langle\mathrm{K}\rangle \Rightarrow\langle\text { ОЛМ }\rangle\langle\mathrm{K}\rangle \Rightarrow \mathrm{У}\langle\mathrm{K}\rangle \Rightarrow \mathrm{У}\langle\text { ФШ } \Rightarrow \text { У тушди }
$$

А белгиси томонидан хосил қилинган ва фақат терминал белгиларидан иборат бўлган сатрлар, L (G) тилини ташкил қилади (улар тил гаплари деб аталади). Мисол. $\mathrm{L}\left(G_{0}\right)=\{$ олма тушди, у тушди $\}$

$\mathrm{L}\left(G_{0}\right)$ тилида 2 тўғри гап бор, $\mathrm{L}\left(G_{1}\right)$ тилида уларнинг сони чексиз. Бу $G_{1}$ грамматикасининг рекурсивлиги натижасидир. Хар бир гапга камида битта келтириб чиқариш қоидаси тўғри келади. Бироқ, бир нечта келтириб чиқариш келтириб чиқариш битта гапга мос келиши мумкин. Мисол. $G_{0}$ грамматикада $У$ тушди қатори $<\Gamma>$ қаториниг хосиласи:

$$
<\Gamma><\text { Э }><\mathrm{K}>\Rightarrow<\text { Э }><\text { ФШ }>\Rightarrow<\text { Э }>\text { тушди } \Rightarrow<\text { ОЛМ }>\text { тушди } \Rightarrow \mathrm{У}
$$


тушди

Келтириб чиқариш чап томонлама дейилади, агар хар бир қадамда чап ўзгаручи алмашса ва келтириб чиқариш ўнг томонлама дейилади, агар ўнг ўзгарувчи алмашса.

Чап томонлама келтириб чиқ̧арищ:

$\langle\Gamma\rangle \Rightarrow\langle Э\rangle\langle\mathrm{K}\rangle \Rightarrow\langle\mathrm{OЛМ}\rangle\langle\mathrm{K}\rangle \Rightarrow \mathrm{У}\langle\mathrm{K}\rangle \Rightarrow \mathrm{У}\langle$ ФШ $\Rightarrow \Rightarrow$ У тушди

Ўнг томонлама келтириб чик̧арищ:

$<$ Г $><$ Э $><\mathrm{K}>\Rightarrow<$ Э $><$ ФШ $>\Rightarrow<$ Э $>$ тушди $\Rightarrow<$ ОЛМ $>$ тушди $\Rightarrow$ У

тушди

Келтириб чиқаришни синтактик дарахт деб тасаввур қилиш мумкин, ёки бошқача қилиб айтганда келтириб чиқзариш дарахти ёки тахэил дарахти.

Агар хеч бўлмаганда битта гап биттадан кўп синтактик дарахтга эга бўлса, ноаниқ (бирқиймали эмас) грамматика деб аталади.

Танлаш масаласига тескари масала - тахулил масаласи. Генеративга тескари қаторларни ўзгартириш құаторлар редукцияси ( мураккабдан соддага ўтиш) дейилади.

$y \in V^{*}$ қатор тўғридан тўғри $x \in V^{*}$ қаторга келади, агар $x$ тўғридантўғри $y$ ни хосил қилса . $y \in V^{*}$ қатор $x \in V^{*}$ қаторга келади, агар $x y$ ни хосил қилса.

Синтактик тахлилининг асосий масаласи, тилдаги берилган гапнинг тахлилини топишдир. Агар тахлили мавжуд бўлса, у холда гап синтасис жихатидан туғри. Тахлил, уни структурасини беради (синтактик дарахтини). Тахлил масаласини хал қилувчи алгоритм англовчи дейилади.

\section{Фойдаланилган адабиётлар:}

1. Булыгина Т.В., Крылов С.А. Модель // Языкознание. Большой энцикло- педический словарь / Гл. ред. В.Н. Ярцева. - 2-е изд. - М.: Большая Российская энциклопедия, 2000. - стр.304-305

2. Juraeva N. V., The formal model of the grammar of the uzbek language . European Journal of Research and Reflection in Educational Sciences// Vol.8 No. 4,2020 Part II ISSN 2056-5852., pp. 129-133.

3. Juraeva N.V., Sultanov R.O., Abdullaeva S.A., Rakhimjonova V. A. Systetization uzbek language word combinations. Международный журнал «Наука и мир». Vol.II. No. 6(82), 2020. ISSN 2308-4804., стр. 65-68.

4. Жураева Н. В., Жураева У. В. Формальные модели членов 
предложения грамматики узбекского языка в рамках официально-делового стиля. Теория и методика профессионального образования. Universum. Психология и образование.12(78). 2020. 